\title{
De Gustibus. Arguing about Taste and Why We Do It
}

\author{
Peter Kivy \\ Oxford: Oxford University Press, 2015, xii+173 or.
}

DOI: $10.1387 /$ gogoa.17257

Zergatik eztabaidatzen dugu arteaz? Zertaz ari gara Mozart Bruckner baino hobea dela diogunean? Ba al du zentzurik esateak Sarrionandia poeta hobea dela Atxaga baino? Lertxundiren nobelak hobeak direla Saizarbitoriarenak baino? Baieztapen horien aldeko nahiz kontrako arrazoiak ematen hastea alferlana al da?

De gustibus non disputandum est dio latinezko esaerak; gustuei buruz ez da disputarik, alegia. A chacun son goût diote frantsesez. Lokuzio horiek guztiek herri-jakindurian oinarritutako egiarik batere jasotzen badute, antzuak dira gustuei buruzko ika-mikak. Itxurazkoak, benetako mamirik gabekoak arteari buruzko desadostasunak. Funtsik gabeak musika-, literatura-, zine-, pintura-, eskultura- eta antzerki-kritikak: kritikari bakoitzaren gustuaren adierazpenak besterik ez. Badakigu: zenbat buru, hainbat gustu.

Eta, hala ere, eztabaidatzen dugu gustuaz eta arteaz, maiz sutsuki eztabaidatu ere. Nola liteke? Izaki irrazional hutsak ote gara, eztabaidagai ez denaz eztabaidatzeko saio hutsalean petralduta? Galdera horiei heltzen die Peter Kivyk liburu labur honetan. Liburuaz aritu baino lehen Kivyri berari buruzko ohar batzuk egingo ditut, ordea. Eta Kivyri buruzko oharrak egin baino lehen, berriz, estetikari eta filosofiari buruzko azalpen batzuk ematea komeni da akaso, alor horiek apenas landu baitira Gogoan.

Sobre gustos no hay nada escrito diote gaztelaniaz. Hitzez hitz hartuta, argi dago, argi dagoenez, ez dela egia. Beste kontu asko bezala, filosofo greziarren gogoeta-gaien artean izan ziren poesia, musika eta antzerkia, gutxienez. Eta idatzi zuten gustuei buruz filosofo haiek. Nork ez du gogoan poetak errepublikatik botatzeko gomendio platonikoa? Artearen filosofiak gutxienez bi mila eta bostehun urte baldin badauzka, artea bera askoz zaharragoa da, jakina. Zenbat urte dira Santimamiñeko edo Ekaingo gure arbasoek kobazuloetako hormak margotu zituztela? 
Artea jarduera zaharra da. Arte ederren kontzeptua, ordea, ez da horren zaharra. XVIII. mendekoa da, eta garai hartan pintura, eskultura, arkitektura, musika eta poesia biltzen zituen. «Estetika» hitza ere garai hartakoa da, gustuari eta edertasunari lotua betiere. Estetikak aparteko tokia hartu zuen Hume eta Kant filosofo handiei esker.

Guztietan berrienak, dudarik ez, artearen filosofia eta estetika analitikoak dira. xx. mendearen erdialdean hasi ziren, filosofia analitikoa bera hasi eta mende erdi bat geroago gutxienez. Atzo. Frege, Russell eta Mooreren kezkak, jakina, beste batzuk ziren, XIX. mendearen hondarretan eta Xx.aren hastapenetan filosofia egiteko modu analitikoa bultzatu zutenean. ${ }^{1}$ Neo-positibistek propietate eta predikatu behagarriei emandako lehentasunak ere apenas utzi zion tokirik propietate eta predikatu estetikoei buruzko eztabaidari. Eta filosofo analitikoek estetikari buruz egindako lehen lanek ere ez zieten estetikari eta artearen filosofiari harrera onik egin. Estetikari edo arteari buruzko esaldiek ez omen dute eduki faktualik. Balio kontuez ari dira, eta esanahi kognitiborik gabe bihurtzen ditu horrek; ezagutza bilatzen duen zientzia- eta filosofia-jardunetik kanpokoak.

1954. urtean aurki daiteke estetika analitikoaren mugarri nagusia. Urte horretan argitaratu zen, William Eltonek atondua, Aesthetics and Language liburua. Bertan biltzen dira Gilbert Rylek, Stuart Hampshirek, O.K. Bowsmak, John Passmorek eta beste filosofo analitiko ezagun batzuek hainbat aldizkaritan argitaratutako artikuluak. Eltonek berak argi asko azaltzen du estetikari eta arteari buruzko gogoeta filosofiarako berreskuratzea dela helburua, ordu arteko filosofia kontinentalaren «mordoilo ilunari», «orokorkeriaren zamari», «esentzialismorako joerari» edo «analogia okerrei» aurre eginez. Estetika analitikoari hasiera berria emateko asmoz ekiten diote lanari, Urmsonek garai bertsuko beste artikulu baten lehen paragrafoan dioen bezala:

Filosofoek dezente egin dute aitzurrean estetikaren lursailean, baina hazi dituzten landareak ale penagarri, ahul eta nahasiak dira. Ez da garaia iritsi, beraz, lursailaren bazterren bat txukuntzeko; berriz iraultzen hasi beharra dago, barazki sendoagoa eta iraunkorragoa, eta osasuntsua izango dena ere, ekarriko duen esperantzan. Ez dut, beraz, aitzakiarik erabiliko nire ustez estetikaren problema nagusia dena berriz irekitzeko. (Urmson 1957, 75 or.) $)^{2}$

\footnotetext{
1 Filosofia analitikoaren eta hizkuntzaren filosofiaren hasieran berean Fregek (1892) eta Russellek (1905) fikzioari buruz edo, zehatzago esanda, fikziozko izen propioei buruz egindako ohar laburrek, hala ere, izan dute oihartzuna geroko estetika analitikoko eztabaidetan.

2 Philosophers have hoed over the plot of aesthetics often enough, but the plants they have raised thereby are pitifully weak and straggling objects. The time has therefore not yet come for tidying up some corner of the plot; it needs digging over afresh in the hope that some sturdier and more durable produce may arise, even if its health be rather rude. I therefore make no excuse for reopening what seems to me to be the central problem of aesthetics. (Aipamen guztiak ingelesetik neronek euskaratutakoak dira).
} 
Urte haietatik aurrera, estetika analitikoa, lursaila aitzurrez nahiz goldez iraultzeaz gain, hazi egokiak aldatu ditu, barazki ederrak lortu, eta bazterrak txukuntzen ere hasia dela esan daiteke. Eta lan horietan urte luzetan aritu direnen artean, Peter Kivy dugu autorerik garrantzitsuenetakoa.

Lehen liburua, Speaking of Arts, bere doktorego-tesian oinarritutakoa, 1973koa da. Azkena, De Gustibus, kritikatzera goazen hauxe, iazkoa. Bitartean, beste ia 30 liburu idatzi ditu. Monografikoak batzuk, artikuluen bildumak besteak. Gehienak musikaren filosofiari buruzkoak idatzi ditu -The Corded Shell (1980), Sound and Semblance (1984), Sound Sentiment (1989), Music Alone (1990), The Fine Art of Repetition (1993), Music, Language and Cognition $(2007)^{3}$...-, baina baita literaturaren filosofiari - The Performance of Reading (2006), Antithetical Arts (2009)... - eta oro har artearen filosofiari eta estetikari buruzkoak. Inork Kivyren lanen batekin hasi nahiko balu, gai hauetaz askorik irakurri ez badu ere, The Possesor and the Possesed (2001) harribitxia iradokiko nioke. Musikarako (eta, bide batez, arterako) jenio ideiaren analisia egiten du, Handel, Mozart eta Beethovenen talentuen azterketaren bidez. Testu gogoangarria da ideien historiazale, filosofiazale nahiz musikazale ororentzat. Edo hala iruditzen zait niri.

Egia esan Kivyri irakurri dizkiodan testuak filosofo onenen idatziek lortzen duten ezaugarri baten jabe dira: filosofia analitikoaren bertute nagusiak dituzte, haren bizio arruntenetan erori gabe. Alegia, hizkuntza argia darabilte eta zehaztasuna argudioan, baina ederki saihesten dituzte gehiegizko bihurgune analitiko jasanezinak, ahistorizismo harroa eta idazkera lehorra, esate baterako. Aldeak alde, Kivyren idazkerak David Humeren, Bertrand Russellen edo John Perryren testuak dakarzkit gogora. Perryren eta Kivyren kasuetan, gainera — desadan bide batez-, bat datoz egilea eta obra. Zorrotzak baina atseginak, jakintsuak baina umilak, serioak baina sentiberak, eta umore finekoak dira bien ala biak.

De Gustibus hau latzagoa da The Possesor and the Possesed baino. Baina ez da latza. Filosofia lana da, baina, analitikoa izanda, ez da batere iluna. Alderantziz, argia da, zehatza; baina ez horregatik astuna. Sakona da mamiz; ez, ordea, itxuraz.

Zertaz ari gara gustuez ari garenean? Zergatik eztabaidatzen dugu gustuez? Horiek dira Kivyk erantzuten dituen galderak 15 kapitulu nahiko laburretan.

\footnotetext{
${ }^{3}$ Azken honen izenburua bertako artikulu batetik dator, eta horren jatorriak Donostiarekin dauka lotura. 2001eko Zientzia Kognitiboko Nazioarteko Kongresura gonbidatu genuen Kivy eta musika, hizkuntza eta kognizioari buruzko hitzaldia egitea proposatu genion. Emaitza Korta eta Larrazabal (2004)n argitaratu genuen. Bitxiak, harrigarriak eta pozgarriak dira batzuetan filosofiak bati zabaltzen dizkion bideak eta ekartzen dizkion enkontruak.
} 
Abiapuntua konstatazio bat da. Eztabaidatzen dugu gustuei buruz. Joera daukagu besteekin partekatzen saiatzeko gure uste eta zaletasun estetikoak. Gure jarrera estetikoak besterenganatzen saiatzen gara maiz. Horixe bera gertatzen da gure uste eta jarrera etikoekin ere. Besteak konbentzitzen saiatzen gara. Gurekin bat etor daitezen nahi dugu. Hori zergatik egiten dugun, hala ere, ez da begi-bistakoa, estetikaren kasuan batez ere.

Etikaren alorrean nahiko garbi dago gure jarrera eta uste etikoek ondorio zuzenak dauzkatela pertsonen ekintzetan eta, beraz, elkarbizitzan. Naturala da, beraz, ekintza onak ekarriko bide dituzten uste eta jarrera etiko ontzat hartzen ditugunak besteek ere onar ditzaten saiatzea. Baina gustu eta jarrera estetikoen kasuan zein zentzu dauka horrek? Uste eta jarrera estetikoek ezertan eragiten al diote ekintzari? Ez uste etikoen maila berean, bedaio. Eta orduan zergatik segitzen dugu eztabaidan? Zentzugabea al da bestea gustu eta uste estetiko propioez konbentzitzen saiatzea?

Peter Kivyk, ez baita filosofo analitiko ohikoa, estetikaren hasieraren garaiko filosofoengana jotzen du lehenik, erantzun bila. Argi uzten du ez duela estetikaren historia egin nahi, baina ezinbestekotzat jotzen du Ilustrazioko filosofoen lanari erreparatzea, haien lanetan baitaude formulatuta antzeko kezkak. Zazpigarren kapituluan eta, batez ere, hamargarren kapitulutik aurrera heltzen dio Kivyk, aurrekari historikoen eztabaida albo batera utzita, bere proposamen propioaren azalpenari. Segidan liburuaren kapituluen laburpen zabala dator. Kapitulu motz samarren laburpen zabal samarrak, ateratako irakaspenak ugariak direlako. Eta liburuak hala merezi duela dirudielako. Bukaeran irakaspen horietako bati egingo diot azpimarra.

David Hume da lehen kapituluaren protagonista. «Humeren dilema» $(\mathrm{Hu}$ me's dilemma) da kapituluaren izenburua. Alde batetik, «The Sceptic» (1742) lanean, indartsu baiezten du Humek gogoaren mendekoa dela edertasuna. Edertasuna ez dagoela gauzetan, gauzak ikusten dituen gogoan baizik. Baina, beste alde batetik, batzuetan gustuari buruzko printzipio orokorrik ere badagoela dio. Hitzez hitz: «Bada zerbait hurbiltzen dena gogo gustuen printzipioetara; eta kritikariek egiantzerago arrazoitu eta eztabaidatu dezakete sukaldariek eta perfumegileek baino» (Hume 1742/1987, 163 or.) ${ }^{4}$. Eta hori esan eta berehala, azken finean, gustuari buruzko eztabaidetan arrazoidunik ez dagoela esaten du, berriz. Askok ulertu dute Humeren pentsamenduaren hariaren azken mutur honek irabazten duela, tartean, Immanuel Kantek berak.

Humeren jarrera zein den ulertzearren «Of the Standard of Taste» (1757) testura jotzen du hurrena Kivyk. Testu horretan bi iritzi kontrajarri horien adierazpen argiak daude: edertasuna ez dago gauzetan, ikuslearen gogoan baizik;

\footnotetext{
4 There is something approaching to principles in mental taste; and critics can reason and dispute more plausibly than cooks or perfumers.
} 
bakoitzak dauka daukan gustua eta, beraz, ez dauka zentzu handirik gustuei buruzko ika-mikak. Eta berdin balio du horrek gogo-gustu kontuentzat nahiz gorputz-gustukoentzat; hots, arte-kontuentzat nahiz sukaldaritzakoentzat.

Gustuen «subjektibismo» erabatekoari kontrapuntua jartzen dio $\mathrm{Hu}$ mek, ordea, eta aurrekoa bezain sen onekoa dela dioen nozio bat aurkezten du. Inork esango baligu Ogilby eta Milton jenio eta dotoretasun bereko poetak direla, dio Humek, ez gintuzke gutxiago harrituko «sator-pila bat TENERIFE bezain altua dela, edo putzu bat itsasoa bezain zabala» ${ }^{5}$ esan baligu baino (Hume 1757/1987, 230-1 or.).

Nondik letorkieke objektibotasuna halako baiezpen estetikoei, Humeren ustez propietate estetikoak gauzetan ez eta gogoan baldin badaude? Soluzioa kualitate sekundarioen ontologiaren bidetik dator. Koloreen metafisikaren antzekoa izango lukete propietate estetikoek. Koloreak ez daude objektuetan, objektuok begiratzen dituen gogoan baizik. Baina uniformitatea badago objektuen propietate fisikoen eta, argi-kondizio normaletan, pertsona osasuntsuaren begiak ikusten dituen koloreen artean. Koloreetarako, «pertsona osasuntsuaren begia»ren tokia «arte ederren benetako epailea»k hartzen du edertasunaz ari garenean; eta epaile horri behar duen izaera emango diona, berriz, horrela deskribatzen du: «Zentzu indartsua, sentimendu delikatuari lotua, praktikak hobetua, konparazioak perfekzionatua, eta aurreiritzi orotik askatua», eta halako kritikarien «epai bateratua da... gustu eta edertasunaren estandar egiazkoa» (Hume 1757/1987, 241 or.) ${ }^{6}$.

Ederraren (eta itsusiaren) metafisikak eta a posteriori ezagugarri diren estandarren edo printzipioen existentziak justifikatzen dute, beraz, gustuei buruzko eztabaida. Eztabaida horrek badu mamia. Milton Ogilby baino poeta hobea dela esatea ez da «Milton Ogilby baino gehiago gustatzen zait»en baliokide. Bigarrenari kontrakoa esatea gauza bat da («Ez, ez zaizu Milton Ogilby baino gehiago gustatzen»); lehenari kontrakoa esatea, aldiz, beste bat oso ezberdina («Ez, Milton ez da Ogilby baino poeta hobea» edo «Ogilby Milton bezain poeta ona da»). Bigarren kasuan, kontrakoa esateak zentzua daukanik ere ez dago batere garbi. Ez behintzat «Ba Ogilby Milton baino gehiago gustatzen zait niri» esateak leukakeen adina zentzu. Baina, argi asko, kasu horretan ez dago kontraesanik. Bakoitzak bere gustu pertsonalaren adierazpena egin du. Biak dira bateragarri. Zenbat buru, hainbat gustu.

Lehen kasuan, aldiz, benetako kontraesana dago: batek $p$ proposizio bat baiezten $\mathrm{du}$; besteak, berriz, ez- $p$ baiezten du, edo ez- $p$ inplikatzen duen pro-

${ }^{5}$ [if he had maintained] a mole-hill to be as high as TENERIFE, or a pond as extensive as the ocean. (Letra larri txikiak Humek zerabiltzan izen propioak eta horietatik eratorritako adjektiboak idazteko. Millerren edizioari segiz, nik ere bere horretan eman ditut).

${ }^{6}$ Strong sense, united to delicate sentiment, improved by practice, perfected by comparison, and cleared of all prejudice... and the joint verdict such... is the true standard of taste and beauty. 
posizio bat. Halakoak ez dira, Humeren ustez, gustu pertsonalaren adierazpenak. Milton Ogilby baino poeta hobea dela egiazkoa da. Horren ukazioa, ostera, faltsua. Halako ika-mika batek, beraz, badu mamia.

Kivyren iritziz, ordea, hori ez da besterik gabe nahikoa disputa estetikoak zergatik egiten ditugun esplikatzeko. Egia zabaltze hutsagatik eusten ote diogu gure uste estetikoen aldeko eztabaidari? Humek ez du horren azalpenik ematen. Kantek ematen ote duen aztertzen du hurrengo kapituluan Kivyk.

Bigarren kapituluan (A Ground Common to All) Kivyk ez du xehe aztertu nahi estetikari buruzko Kanten lana, Judizioaren Kritika (edo Hirugarren Kritika). Baina, hasteko, haren ezaugarri nagusiak azaltzen ditu. Estetikan ere Humek esnatu omen zuen Kant bere «lozorro dogmatiko»tik. Bien ala biek «estetika» gaur egun baino zabalago ulertzen zuten. Gugan plazer-sentimendu jakin bat eragiten duenari esaten diogu «eder». Eta sentimendu horren pean datozen gorputz-gustuei buruzko judizioak (jaki «goxoa» edo «nazkagarria») edo gogo-gustuei buruzko judizioak (artelan «ederra» edo «itsusia»), guztiak dira estetikoak, hala Kanten nola Humeren arabera. Hirugarren Kritikaren 7. atalean, hala ere, «atsegina» eta «ederra» kontrajartzen ditu Kantek. Atseginari dagokionez, betetzen da bakoitzak bere gustua daukala dioen esaera. Baina ederrari buruz ari garenean, gauzak ez dira horrela. Edertasuna gauzen propietatea balitz bezala hitz egiten dugula dio Kantek. Eta gainera besteen adostasuna bilatzen dugula, gure edertasun juzguak egitean. Eta ezberdin epaitzen duenari gustua ukatzen diogu. Edertasunari buruz ez dago, beraz, Kanten ustez, buru adina gustu.

Ezaguna da, baita ere, Kanten ustez, guk judizio estetiko esaten diogun horrek, hots edertasunari (eta itsustasunari) buruzko judizioak, purua, desinteresatua izan behar duela, itxuraren forma hutsera bildu behar duela:

Orain, galdera denean zerbait ederra ote den, ez dugu jakin nahi guri, edo beste inori, inporta ote zaion, edo inoiz inportako ote litzaiokeen gauzaren existentzia, baizik eta nola juzgatzen dugun kontenplazio (intuizio edo hausnarketa) hutsean oinarrituta... Batek jakin nahi duen guztia da ea objektuaren errepresentazio hutsa nire gustukoa den, errepresentazio horren objektuaren existentziari buruzko nire axolagabetasuna gorabehera. Nahiko agerikoa da objektua ederra dela esan ahal izateko eta gustua badudala erakusteko, errepresentazio horrekin nire baitan egin dezakedanean datzala guztia, eta ez ni objektuaren existentziaren mendeko bihurtzen nauen inolako faktoretan. Guztiok onartu behar dugu interes-arrastorik txikiena daukan ederrari buruzko judizioa oso partziala dela, eta ez gustu judizio hutsa. ${ }^{7}$ (Kant 1790, 36-7 or.; §2).

\footnotetext{
${ }^{7}$ Now, where the question is whether something is beautiful, we do not want to know, whether we, or any one else, are, or even could be, concerned with the existence of the thing, but rather how we judge
} 
Artelanaren pertzepzio desinteresatua beharrezkoa da Kanten ustez, baina ez du zertan nahikoa izan. Oso litekeena da bi pertsonak, objektu bera desinteresatuki hautemanda, bakoitzak bere interes guztiak alde batera utzi eta kontenplazio hutsera bilduta, judizio ezberdinekin bukatzea. Beste zerbait behar dugu adostasunera hel gaitezkeela uste izateko. Eta beste hori «oinarri», «lur» edo «zoru komuna» da. Gure juzgu estetikoek oinarri komun hori aurresuposatzen dute inplizituki. Horrekin Kantek zer esan nahi duen esplikatzeko lan polita egiten du Kivyk. Hiru puntuotan laburtzen du gure gaiari, hots gure ika-mika estetikoen esplikazioari, Kantek egiten dion ekarpena:

- Bat. Kantek arrazoi du esaten duelarik ederrari buruzko juzguetan besteengandik adostasuna espero dugula, eta besteak konbentzitzen saiatzen garela. Ez diogu ihes egiten gustuari buruzko disputari.

- Bi. Kantek arrazoi du, baita ere, esaten duenean aurreko jokabide horrek zentzurik izateko, inor gure gustu-judizioei buruz konbentzitzeko esperantza izatea arrazoizkoa izateko alegia, beharrezkoa dela oinarri komun bat partekatzen dugula aurresuposatzea. Oinarri komun hori Kantek dioena izatea beste kontu bat da (Kivyk ez du uste oinarri komun hori irudimenaren eta adimenaren jolas librea denik). Baina oinarri komuna aurresuposatzean zuzen zegoela uste du.

- Eta hiru. Nolanahi ere, Kant zuzen zegoen besteen adostasuna lortzeko joera hori zergatik daukagun esplikatu beharra adieraztean, nahiz eta Kivy bera ez dagoen ados Kanten azalpenarekin.

Horiek horrela, Kivyk erantzunaren bila segitu beharra dauka. Zergatik dauzkagu eztabaida estetikoak? Eta atzera begiratuz segitzen du, XvIII. mendeari erreparatzen segitzen du hirugarren kapitulu laburrean. Estetikari buruzko diskurtsoa etikari buruzkoarekin konparatzeaz jarduten du (The Beautiful versus the Good (in the Eighteenth Century)), eta Francis Hutchensonen eta John Balguyren ikuspegiak aurrez aurre jartzen ditu. Konparazioaren emaitzak zeharo ezberdinak dira bi kasuotan. Lehenengoarentzat subjektiboak dira bai judizio estetikoak eta baita etikoak ere. Kualitate sekundarioei buruz ari dira, Lockeren zentzuan. Balguyk, hasiera batean, judizio estetikoak subjektibo eta etikoak, berriz, objektibo jotzen ditu. Baina gero dio, Hutchensonek bezala, eremu estetikoko eta etikoko propietateek izaera bera dutela.

\footnotetext{
it on the basis of mere comtemplation (intuition or reflection)... All one wants to know is whether the mere representation of the object is to my liking, no matter how indifferent I may be to the existence of the object of this representation. It is quite plain that in order to say that the object is beautiful and to show that I have taste, everything turns on what I make of this representation within myself, and not on any factor which makes me dependent on the existence of the object. Everyone must allow that a judgement on the beautiful which is tinged with the slightest interest, is very partial and not a pure judgement of taste.
} 
Beretzat, hori bai, «ona» eta «ederra» predikatuek munduko propietate objektiboak designatzen dituzte, ez subjektiboak.

Etikoa denaren eta estetikoa denaren arteko konparazioa (edo, batzuetan, ikusi berri dugunez, identifikazioa) ariketa arrunta izan da filosofian eta, xx. mendearen erdi aldean ere, estetika analitikoaren erdiminetan, naturala da konparazio hori. Horren berri ematen du laugarren kapituluan (Simple Emotivism). Positibismo logikoaren emaitza gisa dator etikaren emozio teoria, edo emotibismoa, eta baita geroagoko aldaera den espresibismoa ere.

Hasteko, A. J. Ayerren kasua eztabaidatzen du Kivyk. Ayerren jarrera nagusia honako hau da: balio-kontuetan (etikan eta estetikan, alegia) ez dago benetako disputarik. Ayerrek Language, Truth and Logic ezagunean dioenez, «ekintza mota bat zuzena edo okerra dela esatean, ez dut inolako baiezpen faktualik egiten, ezta nire gogo-egoerari buruzko baiezpenik ere» (Ayer 1936, 107-8 or.). ${ }^{8}$ Horrelako esaldi bat egiten duenak, beraz, ez du proposiziorik ere adierazten. Bi gauza egiten ditu, hala ere: sentimendu (sentiment) moral bat adierazi, batetik, eta sentimenduak (feelings) pizten saiatu, eta, horrela, ekintzara bultzatu, bestetik. Ez dago, hortaz, etikari buruzko benetako eztabaidarik, eta horretan ari garela dirudienean ere, ez da gertakariei buruzkoa, etikako hizkuntzan jantzitako eztabaida besterik. Norbaitekin horrelako eztabaidan hasten garenean «ez gara saiatzen argudioak ematen situazioari buruzko sentimendu moral 'okerra' daukala erakusteko... Erakusten saiatzen gara oker dagoela kasuaren gertakariei buruz.» (1936: 110-11) ${ }^{9}$

Eta etikan gertatzen den horixe bera gertatzen da estetikan ere, Ayerren ustez. «Eder» eta «itsusi» hitzak ez ditugu erabiltzen baiezpen faktualak egiteko, sentimendu jakin batzuk adierazi eta besteengan erantzun jakin batzuk erdiesteko baizik. Kivyk azpimarratzen duenez, diskurtso estetikoan lortu nahi den erantzuna «emozioak komunikatzea» dela dio Ayerrek, eta horrekin ez du soilik esan nahi esaleak berak, kritikariak adibidez, zein emozio sentitzen duen jakinarazi nahi diola entzuleari edo irakurleari. Azken horrek emozio bera bizitzea izango luke helburu, Ayerrek dioenez. Baina zergatik, galdetzen du Kivyk, nahiko luke batek norberak bizi duen emozioa besteek ere bizitzea?

Etikaren alorrean erantzuna ez da zaila. Ekintzara lotua dago etika. Ekintza batzuk bultzatu nahi ditugu, beste batzuk galarazi. Eta besteengan emozio moral egokia eragitea bide naturala da beren ekintza bultzatu edo galarazteko. Emozio morala ekintzarako motibazio naturala da.

\footnotetext{
8 in saying that a certain type of action is right or wrong, I am not making any factual statement, not even a statement about my own state of mind.

${ }^{9}$ we do not attempt to show by our arguments that he has the «wrong» ethical feeling towards a situation... What we attempt to show is that he is mistaken about the facts of the case.
} 
Baina estetikaren kasuan? Bestearengan eragindako emozio estetikoak zein ekintzatara bultzatuko du? Zein ekintza egitea galaraziko dio? Kivyk dioskunez, Ayer bera ere ohartu bide zen etikaren eta estetikaren desanalogia honekin, egiten duen konparazioak puntu batean egiten baitu huts: estetikaren kasuan ez du ekintzarik aipatzen. Eta, ekintzarik gabe, zein da batak besteari emozio estetikoa komunikatzeko arrazoia? Ayerren emotibismoan ez dago erantzun onik. Charles Stevensonen espresibismoan bilatzen segitzen du Kivyk bosgarren kapituluan (Do So as Well).

Stevensonek termino etikoen analisirako bi eredu aurkezten ditu, eta etikarako bi eredu horiek estetikarako ere balio ote dezaketen aztertzen du Kivyk. Hasteko, Stevensonen jarrerak Ayerrenaren oso antzekoa dirudi, baina badu ezberdintasun nabarmen bat: Ayerren ustez, «X ona da» diogunean emozio bat adierazten dugu, proposizio-edukirik gabeko adierazpena egiten dugu. Stevensonen ustez, berriz, geronen gogo-egora baten berri ematen dugu «X ona da» esanez. Esaldiak badu, beraz, eduki deskriptiboa, proposizio-edukia. Baina ez dirudi horrek bestelako garrantzirik daukanik gure gai nagusirako.

Ereduak eredu, eta labur beharrez, Stevensonen ustez «X ona da»ren esanahia beste hauen baliokidea da, gutxi gorabehera: «Gustukoa dut X, izan ezazu zeuk ere» edo «X onesten dut, onets ezazu zeuk ere». Geure gogoegoeraren berri emateaz gain, bestearenganako agindu moduko bat ere barne hartzen du gure judizio etikoak, teoria emotibista (edo espresibista) honen arabera. Ikuspegi honek etikan izan ditzakeen bertuteak eta mugak alde batera utzita, Kivyk dioen bezala, ondo esplikatzen du agindu moduko horren presentzia eta, horren bidez, baita eztabaida etikoaren zergatia ere. Ez da benetako desadostasuna dagoelako - azken batean, oso litekeena da gauza berari buruzko zure gogo-egoera era batekoa izatea eta nirea bestelakoa izatea; bateragarriak dira bi gogo-egoerak-. Besteek gure judizio etikoak bere egitea nahi dugu, ekintzan izan dezakegun «desadostasuna» dela eta. Zure ekintzak nirea galaraz dezake, edo alderantziz. Horregatik, jarrerak partekatu nahi izateko joera.

Hala ere, zer dela-eta izan dezakegu gure jarrera estetikoa ere konpartitzeko joera? Beste behin Kivyk dio judizio estetikoak ez daukala ekintzarako loturarik. Edo aurki diezazkiokegunak erraz baztertzeko modukoak direla. Emotibistak agian ken diezaioke agindu moduko parte hori judizio estetikoaren esanahiari. «X ona da» esatea «X gustukoa dut»en baliokidea litzateke, kito. Baina horri batek «X ez da ona» (= «X ez dut gustukoa») erantzun diezaioke, bizkarrak harrotuz. Eta kito, berriz. Hor bukatuko litzateke eztabaida. Baina ez da hori gertatzen. Ala bai? Horri buruz ari da Kivy seigarren kapituluan (The Aesthetic Shrug).

Kivyren arabera, Kanti aitortu behar zaio filosofia modernoaren hastapenetatik gustuari buruz eztabaida badelako ustea ezartzea. Eta eztabaida be- 
netako eztabaida dela, judizio estetiko zuzen eta okerrekin. Baina Kant bera oker baldin bazen? Akaso eztabaida itxurakoa besterik ez da. Edo, areago, igual ez dago ika-mikarik ere. Juzgu estetikoaren adierazpen baten aurrean, isildu eta bizkarrak harrotu baino ez dugu egiten agian. De gustibus non disputandum est perpausak eduki deskriptibo hutsa izango luke: ez dago eztabaidarik, ez dugu eztabaidatzen, alegia.

Bada horixe bera baieztu duenik. Russ Shafer-Landau, adibidez. Hark ematen dizkigun adibideak ez dira, hala ere, kontuan hartu beharrekoak, Kivyren ustez. Shafer-Landauk errealismo morala defendatzeko judizio moralak eta estetikoak erkatzen dituenean, auzi inozoak jartzen baititu estetikaren aldean: zein da kolore ederragoa, gorria ala laranja? Ez dago horri buruzko ganorazko eztabaidarik. Baina ez auzi estetikoa delako, auzi txepela delako baizik.

Michael Smithen argudio-lerroak mami gehiago daukala deritza Kivyk. Smithek judizio etikoaren eta estetikoaren «fenomenologiak» alderatzen ditu. Haren ustez, desadostasuna morala denean, eztabaida segidan dator, baina estetikoa denean, ez. Kivy ez dago ados. Gerta daiteke jendeak oro har interes gutxiago izatea kontu estetikoetan etikoetan baino. Interesa dutenen artean, ordea, eztabaida eguneroko kontua da, eta besterik esatea gertakariak ukatzea baino ez da. Bestalde, Smithek darabilen adibideak («Zein da artista hobea, Turner ala Pollock?») konparazio estetikoei buruzko ohar interesgarriak egiteko parada ematen dio Kivyri. Batetik, horrelako auzi bat planteatzen denean, isilik geratzeko aukera azaleratzen da. Bi margolari horiek urrun daude denboran eta estiloan, biak ere margolari handiak dira, baina horrek ez ditu konparaezin bihurtzen, Kivyren iritziz. Erantzuna erabakitzen zaila izan liteke (gertuegi egon litezke erabaki ahal izateko); nolanahi ere, galdera ez da berez erantzunik gabea.

Eztabaida estetikorik ezaren jarrera defenditzen duten Björnsonn eta McPherson ez-kognitibista moralen kasua ere aztertzen du Kivyk. Baina hor ere ez du bizkar-harrotzearen eta eztabaidarik ezaren aldeko taxuzko argudiorik topatzen. Bestelako galdera bat egitera bultzatzen du Kivy eztabaida honek. Zerk bultzatzen ditu moralaz ari direnak estetikarekin modu horretan konparatzera? Zergatik iruditzen zaie judizio morala eduki sendoagokoa judizio estetikoa baino? Konparazioak, bestalde, etikaren eta estetikaren arteko funtsezko desberdintasuna ezartzea ez, baizik bien arteko funtsezko lotura izan zezakeen helburu. Hori da, beste behin, Kantek aditzera ematen duena.

Zazpigarren kapituluan (Immoral Art), Kivyk artean, arte ederretan jartzen du arreta, honako galdera honi erantzuna emateko asmoz: gustu ona bertute morala ote da, gustu txarra akats, bizio morala? Erantzunak, baiezkoa balitz, eztabaida estetikoaren motibazioari buruzko erantzuna ere berarekin lekarke: etikak ekintzarekin daukan lotura legoke eztabaida estetikoaren atzean ere. Horretaz aritzeko, arteari eta estetikari buruz daukan jarrera nagusia azaltzen du Kivyk. Eta berezko interesa dauka horrek ere, jakina. 
Hasteko, bereizketa nagusi bat egiten du proposizio-edukia izan dezaketen eta proposizio-edukirik ez daukaten diziplinen artean. Lehenengoek, munduari buruzko edukiak izan ditzateke, eduki moralak barne, hizkuntzazkoak direlako (nobela, poesia, antzerkia...) edo testua daukaten musika, edo errepresentazionalak diren arte bisualak. Musika hutsak (izenburu, testu edo inguru dramatikorik gabeak), aldiz, ez du proposizio-edukirik, Kivyren ustez.

Proposizio-edukirik gabeko diziplinetan «artistikoak» diren propietateak (art-relevant property da Kivyk darabilen terminoa) estetikoak dira denak. Diziplina errepresentazionalen kasuan, berriz, badira artistikoak baina ez-estetikoak diren propietateak. Horien artean daude, esate baterako, lan batek gorde ditzakeen tesi moralak. Ez dira artelanaren propietate estetikoak, baina artistikoak dira, artelanaren meritu edo demerituak, artelan gisa, juzgatzeko pertinenteak direlako. Adibide polit bat ematen du Kivyk hori azaltze aldera: «Haizeak eramana» (Gone with the wind) film ezaguna. Kivyren ustez, filmak dauzkan eduki artistiko moral higuingarriak (esklabotzaren defentsa, adibidez) nahikoak dira bere propietate estetiko on ugariak gainditu eta film txartzat jotzeko. Jakina, beste batek filma goza dezake, eduki moralak alde batera utzi eta propietate estetikoez disfrutatuz, baina hutsegite moraltzat hartuko luke hori Kivyk, eta harekin eztabaidan hasi. Eztabaidan hasteko justifikazioa, orduan, eztabaida moralak daukan berbera izango litzateke.

Eztabaida eduki moral horri buruzkoa izan daiteke, hala ere. Egia al da filmak eduki moral horiek dauzkala? Artelanaren esanahiaren interpretazioari buruzko eztabaidara garamatza horrek. Eta horri dagokionez intentzionalistatzat aldarrikatzen du Kivyk bere burua. Artelan batek esanahi bat edo bestea izateko, artistak hori esan nahi izateko asmoa izatea beharrezkoa da. Baina ez nahikoa. Artistak huts egin baitezake bere asmoa aurrera eramatean. Audientziari zuzendutako esanahi-asmo gricearra aldarrikatzen du Kivyk artelanen esanahiaren interpretazioan.

Edukiak eduki, honako gai honi heltzen dio Kivyk segidan: arte ona gozatu ez, eta arte txarra gozatzea posible da. Immorala ote da, ordea, arte immoralaz gozatzea? Eta, zehatzago, immorala al da artelan immoral batez gozatzea, artelana immorala dela jakinda? Kivyk ez dauka erantzun garbirik. Eta aitortzen du. Uste du baietz. Intuizio hori dauka, baina ez dauka argudio indartsurik. Baiezkoan, erantzun zuzena luke arteari buruz zergatik eztabaidatzen dugun argitzeko. Kontu morala litzateke. Baina ez dago ziur. Eta beste kontu bat aztertzera jotzen du. Propietate estetikoei buruzko gustu txarra izan al liteke akats morala? Horixe aztertzen du zortzigarren kapituluan (Is bad taste immoral?).

«Parametro estetiko hutsetan» gustu txarra (edo ona) daukanak bizio (edo bertute) moral bat ote daukan argitzeko, parametro estetiko huts horiek zer diren argitu behar da lehenbizi. Kivyk ez du definizorik eskaintzen, 
eta adibideen bidez erakusten du buruan zer daukan. Parametro horiek aurki daitezke artelanetan nahiz naturan. Edo baita matematika-lanetan ere. Bada froga logiko baten edertasuna «ikus» dezakeenik ere. Edertasuna —eta itsustasuna (edota itsuskeria?) - hautematearekin zerikusia duten parametroak dira, beraz, parametro estetiko horiek.

Aurrerago ematen ditu Kivyk argibide gehiago. Oraingoz ideia intuitibo horrekin konpondu beharko dugu. Kontua da parametro horiek balioesteko gaitasunik ez daukanak akats morala ote duen. Beste bereizketa bat egiten du horri erantzuteko, bi bide ikusten baititu zerbaitek meritu/demeritu morala izateko: instrumentala eta intrintsekoa edo berezkoa. Filosofo moral zahar askok, diosku Kivyk, uste zuten animalienganako krudelkeria ez zela berez txarra, baina pertsonenganakoa bai. Animaliak krudelki tratatzeak izan zezakeen eragin txarrik, ordea: pertsonaren izaera alda zezakeen eta beste pertsonekin krudel bihurtzea ekarri. Pertsonenganako krudelkeria bizio moral intrintsekoa da; animalienganako krudelkeria bizio moral instrumentala da. Hala uste zuten filosofo moral askok (eta hala uste izaten segitzen dutela, gehituko nuke nik).

Hori estetikaren kasura eramanda, gustu ona/txarra bertute/bizio moral instrumentalak direla pentsa dezakegu; edo intrintsekoak direla, bestela. Lehenengo kontua enpirikoki erabaki beharrekoa dela uste du Kivyk. Ikusi egin beharko litzateke gustu ona dutenek izaera moral hobea ote duten; gustu txarra daukatenak moralki txarragoak ote diren. Kivyk aitortzen du ez daukala horrelako ikerketaren berririk, eta, intuitiboki bada ere, ez duela ikusten horrelako loturarik.

Balio moral intrintsekoa ote du gustuak? Horri erantzuteko ez du ikerketa enpiriko posiblerik ikusten; eztabaida filosofikoa izan omen daiteke soilik. Eta esperimentu mentala proposatzen digu. Hartu pertsona normal bat. Gogoko duzu hasieran. Hainbat gustu konpartitzen dituzue, eta baita filosofia-zaletasuna ere, esate baterako. Baina, halako batean, sekulako arrazista dela ohartzen zara: antisemita ikaragarria dela, demagun. Hori nahikoa litzateke harekin harreman oro eteteko, Kivyren ustez. Hartu orain antzeko beste pertsona bat: musika klasikoarekiko zaletasuna konpartitzen duzue, baina, halako batean, Bach gorrotatzen duela esaten dizu, ezin duela haren lanik batere entzun, hain da-eta txarra. Ezin duzu sinetsi. Baina haren lagun izaten jarrai dezakezu.

Kivyren ondorioa da gustu onak/txarrak ez daukala balio moralik, ez berezkorik, ezta instrumentalik ere. Eztabaida estetikoa esplikatzeko ezin dugu, beraz, besterik gabe haren balio moralera jo; ez bada zentzu moral lausoago baten bidetik. Bederatzigarren kapituluan (Push-pin and Poetry) Jeremy Benthamen bidea aztertzen du laburki Kivyk.

Benthamen hedonismoak plazera jotzen du berez ona den gauza bakartzat. Gainerako guztia instrumentalki da soilik ona, eta ekintza zuzena pla- 
zera indartu eta mina saihesten duena da. Horregatik, plazera bada ongiaren neurri bakarra, maila berean har daitezke edozein ume-joko eta poesia, tamaina bereko plazera eragiten badute. Hori guztia estetikaren alorrera ekarrita, igogailuetako musika Mozartena baino hobea izan liteke. Horrelako ondorioak saihestearren, John Stuart Millek plazeraren kalitatea sartu zuen tartean. Baina hark ere ez du erantzun egokia ematen. Hedonismotik harago joan beharra aldarrikatzen du Kivyk, eta nolabaiteko errealismo estetikoari heldu beharra. Igogailuko musika Mozartena baino txarragoa dela konbentzitzen saiatzeko motibo moralik edukita ere, Mozart entzunez nolabait pertsona hobea izango litzatekeela, hori gertakaritzat jo beharra dago. Hori hala bada, motibo morala ez dugu beharrezkoa esplikatzeko zergatik saiatzen garen inor konbentzitzen. Egiaz konbentzitzea motibo nahikoa da argudioa eta eztabaida esplikatzeko. Hasierara gatoz atzera. Kanten jarrera aztertzera berriz.

Hamargarren kapituluan (Back to Square One) Hume eta Kantengana jotzen du Kivyk beste behin, edertasunaren esperientziaren fenomenologiaz haiek proposatutakoetan argi gehiagoren bila. Kantengandik hasita, judizio estetikoari buruzko haren ikuspegian aurki daitekeen tentsioa eztabaidatzen du Kivyk. Alde batetik, judizio estetikoa subjektibotzat hartzen duela dirudi. Batek «Objektu hori ederra da» bezalako baiezpena egiten duenean, honelako zerbait esaten ari da, Kanten ustez: «Objektu hori ederra da niretzat». Baiezpena objektuari buruzkoa bada, edo objektuaren propietate bati buruzkoa, zeharka baizik ez da halakoa. Zuzenki subjektuari buruzkoa baino ez da. Ederrari buruzko judizioa edo jakien gustuari buruzkoa maila berean leudeke horretan. «Ederra» edo «goxoa» ez dira objektuaren propietateak, haiek gure begian edo ahoan eragiten dutenari buruzkoak baizik.

Hala ere, Kantek berak aldea sumatzen du, bestalde, «gogo-gustu»aren eta «gorputz-gustu»aren artean. Ederrari buruzko judizioan edukia objektiboa balitz bezala hitz egiten dugu; edertasuna objektuarena balitz bezala. Baina zergatik hitz egiten dugu horrela? Oker gaudelako eta edertasuna objektuaren propietatea ez izanik, hala dela uste dugulako? Kivyk ez du uste hori denik Kanten jarrera. Kanten ustez, jakinaren gainean hitz egiten dugu edertasuna objektiboa balitz bezala; badakigu subjektiboa dela. Eta, hala ere, besteen adostasuna lortzen saiatzen gara. Eta zergatik hori? Kanten jarreran «adostasuna» baino "partekatzea» da hitza. Sentimendu bat partekatu nahi dugu gure kideekin. «Ederra» esatera eraman gaituen sentimendua.

Humek edertasunaren esperientziaren fenomenologia desberdina proposatzen du, nahiz Kanten abiapuntu bera izan. Judizio estetikoa subjektiboa da, baina, Humeren ustez, objektuek eragiten diguten sentimendua objektuei proiektatzeko joera daukagu. Eta beste kasu batzuetarako proiekzio kontu hau gehiegizkoa izan badaiteke ere, Kivyren ustez, esperientzia estetikoaren fenomenologiaren kasuan bete-betean asmatzen du; Kantek kale egiten duen neurri berean asmatu ere. 
Koloreen esperientziaren fenomenologiaren parekoa da, Humeren ustez, esperientzia estetikoa. Objektuak edertasun-«sentimendua» eragiten du gugan, gorritasun-sentsazioa eragiten duen era berean. Edertasun sentimendu hori, nahiz gorritasun sentsazioa, objektuarena balitz bezala bizi dugu. Ez gara gure egoera subjektiboaz, gero objektuan proiektatuko dugun horretaz, jabetzen. Objektuak edertasun- edo gorritasun-propietatea izateaz jabetzen gara soilik. Fenomenologia hori izanda, guztion esperientzia ere berdina da; guztiok hartzen dugu edertasuna objektuaren propietatetzat. Batzuek, gainera, hala dela uste dute: Milton Ogilby baino hobea dela objektiboki. Beste batzuek ez dute horrelakorik onartzen: bakoitzak izango bailuke bere gustua. Baina azken hauek ere, Humeren ustez, objektiboa balitz bezala bizi dute.

Kivyren iritzian, fenomenologia zuzena ematen du Humek, bere metafisika gorabehera. Okerra Kantek. Honen ustez, bere egoera subjektiboaz, Humek «sentimendu» esaten dion horretaz, ohartzen da pertsona, eta horregatik baiezten du objektuaren «edertasuna». Ez du edertasuna objektuaren propietatetzat hartzen. Hizkeran darabil horrela, baina hala dela uste izan gabe. Eta Kivyren ustez, hori ez da horrela.

Humeren eta Kanten fenomenologiak garai bereko beste filosofo eskoziar batenarekin alderatzen ditu: Thomas Reid filosofoarenarekin. Reid, Hume eta Kant ez bezala, errealista estetikoa da. Propietatea objektuarena dela esaten du. Eduki objektiboa du judizio estetikoak. Eta hori osagarria da Humerena bezalako fenomenologia batekin. Gure esperientzian edertasuna objektuena da, azkenean, edertasuna objektuena delako. Ikusiko dugunez, Kivyk ere errealismo estetikoa defenditzen du: gure judizio estetikoen egia faktuala. Eta hurrengo kapitulutik hasten da bere argudioa eraikitzen, propietate artistikoen eta estetikoen artean hainbat mailatako bereizketa egiten duenean.

Nolanahi ere, hamaikagarren kapitulua ere (The Right Phenomenology) fenomenologiari buruzkoa da. George Santayanaren proposamena aztertzen du Kivyk. Humeren antzeko jarrera dauka judizio estetikoari buruz Santayanak. Harenari bezala, errealismo subjektiboa esan dakioke Santayanaren jarrerari. Errealismoa, defenditzen duen fenomenologiagatik. Edertasuna kontu objektibo gisa bizi dugu. Subjektibismoa, jarrera ontologikoagatik. Gure esperientziak esperientzia, edertasuna pertzepzioan dago, ez objektuan. Nolanahi ere, Santayanak XVIII. mendeko filosofoek kontuan hartu ez zuten auzi bati egiten dio aurre. Judizio estetikoei buruzko desadostasunak eta argudiatzeko daukagun joera esplikatzeko urratsa ematen du. Edertasuna kontu objektibo gisa bizi badugu, besteak ere egiaz jabetzeko xedez eztabaidatzen dugu, egia tartean dagoen guztietan egiten dugun arrazoi beragatik.

Kivyren ustez, Humeren, Reiden eta Santayanaren bidetik datorkigu esperientzia estetikoaren fenomenologia zuzena. Edertasuna errealismo estetikoa egiazkoa balitz bezala bizi dugu. Eta hori erraz samar eraman daiteke 
artelan sinpleen kasura. Katedral baten edo sinfonia baten kasuetan, agian, konplikatuxeagoa izan daiteke.

Kapitulu honetan hasten da Kivy estetikari eta artearen filosofiari buruzko bere ikuspegi orokorraren egitura azaltzen. Lehendabizi, «eder» hitzaren esanahi desberdinak bereizi behar direla esaten digu, XVIII. mendetik gutxienez bereizi izan diren moduan. Alde batetik, termino ebaluatibo orokor gisa erabil daiteke. Artelanaren kalitate altua edo artelan gisa duen arrakasta adieraz dezake. Zentzu honetan, Iliada eta Eneida biak dira eder.

Ebaluatzea baino gehiago deskribatzea xede duen «eder» terminoaren beste erabilera bat ere topatzen da XVIII. mende horretan bertan. Bigarren zentzu honetan, «ederra» eta «sublimea» (edo «gorena», «bikaina», «ezin ederragoa» eta abar) bereiz daitezke. Eta, lehengo adibidearekin jarraituz, Eneida ederra litzateke; Iliada, berriz, sublimea.

«Eder» eta «sublime»ren erabilera deskriptibo horiei esango die Kivyk «termino estetiko». Eta Frank Sibleyk hala deitutakoekin bilduko ditu, hala nola, «lirain», «polit», «fin», «orekatu», «ondo josia»... «Eder» erabilera deskriptibo estetiko honentzat gordeko du eta erabilera ebaluatiboan honako beste termino hauekin ordezkatuko du: «artelan handi», «artelan arrakastatsu», «artelan pobre», eta abar.

«Estetiko» diogunean, bestalde, artelan bat artelan gisa apreziatzeko, deskribatzeko eta ebaluatzeko alderdi oroz ari gara normalean; alde batera utzi gabe, jakina, artelanak ez direnak ere aprezia, deskriba eta ebalua daitezkeela estetikoki. Bestalde, gero eta gehiago bereizten dute artearen filosofoek artelanen propietate estetikoen eta estetikoak ez baina artearentzat errelebante direnen artean (propietate «artistiko ez-estetiko» esango diegu guk, labur beharrez). Artelanak deskribatzeko darabiltzagun «lirain», «dotore», «fin», «orekatu» artelanen propietate estetikoak denotatzen dituzten terminoak dira. Baina nobelagileak bere lanean tesiren bat adierazi badigu, edo filmaren bidez mezu morala, politikoa edo soziala eman nahi izan badu, horiek artistikoki errelebanteak diren arren, ez dira estetikoak (hots, artelanaren propietate artistiko ez-estetikoak dira). Lehen, «Haizeak eramana»ri buruzko eztabaidaren adibidearekin azaldu digu propietate hauen kasua.

Horiek horrela, arteari buruz eztabaidatzen dugunean, gutxienez hiru maila ezberdinetan koka daiteke gure eztabaida. Desadostasuna propietate artistiko ez-estetikoei buruzkoa izan daiteke, edo propietate estetikoei buruzkoa, edo biei buruzkoa. Badago beste aukera bat ere: artelanaren balioari buruzkoa izan daiteke ika-mika. Hiru maila horiei artelanaren «interpretazioa», «analisia» eta «ebaluazioa» esaten die Kivyk, hurrenez hurren. Gure judizio estetikoak, artelanei buruzko gure esaldiak, eta horiekin gure adostasun eta desadostasunak, hiru maila horietakoak izan daitezke gutxienez. Eta horiei eskaintzen dizkie Kivyk hurrengo hiru kapituluak, nire uste apalean behintzat liburuko ekarpen nagusia osatzen duen eztabaidan. 
Kivyren ustez, arteari buruzko eztabaidak hiru maila horietakoak dira. Mamia daukaten eztabaidak dira. Eta eztabaida arrazionalak dira. Bestea konbentzitzeko eztabaidatzen dugu. Hiru maila horietako bakoitzean judizio estetikoaren egia da ezbaian dagoena.

Hamabigarren kapituluan (The Truth of Interpretation) propietate artistiko ez-estetikoak dira gaia. Kivyren tesi nagusia honako hau da: artean interesa daukanak artearen interpretazioaz eztabaidatu egiten du esaten duena egiazkoa dela uste duelako, eta bere ukazioa faltsua.

Artelanen esanahiari buruz ari da interpretazioa. Esanahi hori, Kivyk dio, proposizionala nahiz errepresentazionala izan liteke, eta artelanean dago. Edo, zehatzago esanda, artelanean dagoelakoan eztabaidatzen du artean interesa duenak; ez subjektiboa delakoan.

Interesgarria da Griceren (1957) esanahiaren teoria darabilela Kivyk, artelanen esanahiaren teoria gisa. Artistaren asmoak zeresana du artelanaren esanahian, beraz. Zeresan handia. Baina ez osoa. Bere asmoa igarria izateko moduan gauzatu behar du artistak lana, hiztunak esaldia bere asmoa igarria izateko moduan egin behar duen gisan, Griceren arabera. Bestela esanda, ezin da edozein gauza edonola esan nahi izateko asmorik izan. Asmoa beharrezkoa da, baina ez da nolanahiko asmoa, nolanahi gauzatutakoa.

Artean falazia intentzionalista salatzen dutenekin aurrez aurre jartzen du jarrera Gricezale horrek Kivy, eta eztabaidatzen ditu Monroe Beardsleyren, Roland Barthesen eta Stanley Fishen jarrerak banan-banan. Intentzioak alde batera uzten direnean, esanahiaren objektibotasuna ere alde batera geratzen da, eta, bide horretatik, artearen esanahiari buruzko eztabaida jardun irrazionalaren taldera kondenatzen da, Kivyren ustez. Bere esanahiaren teoria gricearrak, ordea, ederki erantzungo lieke esanahiaren objektibotasuna zalantzan jartzen duten argudioei. Kontu objektiboa da halako egilek halako lana egitean hau-ta-bestea esan nahi izateko asmoa ote zuen, eta halako lanak ba ote daukan aukerarik hura-eta-bestea komunikatzeko. Esanahiaren teoria gricearrak ondo azalduko luke, halaber, batzuetan artelanen esanahia zehazteko daukagun ezintasuna: egilea aspaldikoa izateak zaildu egiten du haren asmoak zein izan zitezkeen asmatzea.

Gustuari buruzko gure eztabaidak ez dira beti artelanaren esanahiari buruzkoak (badira esanahirik gabeko artelanak ere). Izan daitezke artelanaren propietate estetikoei buruzkoak ere. Hori eztabaidatzen du Kivyk hamahirugarren kapituluan (The Truth of Analysis). Musika-kritikariek erabiltzen omen dute «analisia» musika-lanen ezaugarri musikalak deskribatzeaz aritzeko. Eta Kivyk oro har artelanen propietate estetikoen deskripziorako darabil. Eta hasteko propietate estetiko horiek zein diren argitu beharko du.

XVIII. mende hasieran sartu omen zuen Alexander Baumgartenek «estetiko» terminoa, artelanen «eder», «goren» eta «ikusgarri» gisako propietateak 
sailkatzeko. Eta propietate horien ontologia eta epistemologia Frank Sibleyk sartu zituen Xx. mendeko filosofian, «Aesthetic Concepts»1959ko artikuluan.

Sibleyk bi mailatako propietateak bereizi zituen. Alde batetik, artelan bakoitzari bere diziplinan «teknikoak» zaizkion propietateak daude, artearen jasotzaile orok hautematen dituenak. «Lehen mailako» propietate horietan oinarritzen dira beste maila bateko propietate batzuk, gustu edo sentsibilitate berezi baten esku-hartzea eskatzen dutenak. Sibleyk azken horiei soilik esaten die «estetiko». Honako adibideekin argitzen du bi propietate klaseon arteko bereizketa Sibleyk berak:

Eleberri batek pertsonaia kopuru handia duela esaten dugu eta langile-herri bateko bizitzaz ari dela; margolan batek kolore hitsak darabiltzala, urdinak eta berdeak nagusiki, eta belaunikatutako figurak dauzkala lehen planoan; halako puntuan fuga bateko gaia alderantzikatu egiten dela eta stretto bat dagoela amaieran; antzerki-lanaren ekintza egun bateko tartean gertatzen dela eta bosgarren ekitaldian adiskidetze-eszena bat dagoela (...) Bestalde, esaten dugu, baita ere, poema bat ondo josia dagoela eta sakon harrapatu gaituela; irudiak oreka falta duela, edo baduela halako sosegu edo baretasun bat, edo irudien taldekatzeak tentsio kitzikagarria eragiten duela; eleberriko pertsonaiak ez direla inoiz bizitzera iristen benetan, edo pasarte jakin batek faltsu jotzen duela. (Sibley 1959,127 or. $)^{10}$

Sibleyk bereizitako bi propietate klase horien arteko harremanak soka luzea ekarri du estetika analitikoan. Bigarrenei soilik esaten die Sibleyk «estetiko», haiei buruzko juzguak egiteko halako sentsibilitatea edo «gustua» izatea eta erabiltzea eskatzen omen dutelako. Lehenengoei buruzko judizioek, aldiz, ez bide dute halakorik eskatzen. Lehen mailako propietateak kondizioek gobernatuta daude, baina propietate estetikoak ez, Sibleyren iritziz betiere.

Kivyk aitortzen duenez, Sibleyren 1959ko artikulu hau eta bertan egiten den bereizketa daude haren estetikako lanaren iturrian. Doktorego-tesiko lanak horri buruzkoak izan ziren eta baita bere lehen liburuaren motibazio nagusietakoa ere (Speaking of Art, 1973). Sibleyren kontra, lehen mailakoak ere ezaugarri edo propietate estetikoak direla argudiatzen du.

\footnotetext{
${ }^{10}$ We say that a novel has a great number of characters and deals with life in a manufacturing town; that a painting uses pale colors, predominantly blues and greens, and has kneeling figures in the foreground; that the theme in a fugue is inverted at such a point and that there is a stretto at the close; that the action of a play takes place in the span of one day and that there is a reconciliation scene in the fifth act (...) On the other hand, we also say that a poem is tightly-knit or deeply moving; that a picture lacks balance, or has a certain serenity and repose, or that the grouping of the figures sets up an exciting tension; that the characters in a novel never really come to live, or that a certain episode strikes a false note. (Itzulpena Lamarque eta Haugom Olsenek (2004) argitaratutako bertsiotik egina dago).
} 
Baina De Gustibus honetan beste bereizketa bat interesatzen zaio Kivyri gehiago: deskripzio ebaluatiboen eta ez-ebaluatiboen arteko bereizketa. Bigarren mailako propietateak adierazten dituzten terminoak ebaluatiboak dira, nahiz ez izan erabatekoak. Aldi berean deskriptiboak eta ebaluatiboak dira. Artelan bati buruz «dotorea» dela badiogu, artelana deskribatzen ari gara eta, berebat, positiboki balioesten ari gara; ona dela esaten ari garenean balio positiboa duen juzgua egiten ari gara, baina bestelako informazio deskriptiborik eman gabe. Eduki ebaluatiboa duten termino estetikoen artean eduki deskriptiboa dutenei termino «lodi» esango die (thick), eduki ebaluatibo soila daukatenei, berriz, «fin» (thin) Kivyk.

Nik ulertzen dudan heinean, bedaio, lehen mailako terminoek eduki ebaluatibo neutroak dauzkate eta ezin da baztertu besterik gabe bigarren mailako terminoen artean eduki ebaluatibo neutroak dauzkatenak topatzea. «Triste» gisako termino espresiboak, adibidez, ebaluatiboen artean sartzen ditu Kivyk, baina onartzen du eztabaidagarria izan daitekeela.

Ezaugarri hauei guztiei buruzkoa da, beraz, artearen analisia. Termino mota horiek guztiak dira gure judizio estetikoen osagai. Liburuaren gai nagusira itzuliz, galdera orain honako hau da: zergatik eztabaidatzen dugu artelanaren analisiari buruz edo, bestela esanda, bere ezaugarri estetikoei buruz?

Eta guztiei buruz eztabaidatzen al dugu? Erraza da ezetz pentsatzea, nekez egon daitekeelako ezaugarri estetiko «teknikoei» buruzko ganorazko eztabaidarik. Esate baterako, eleberriak pertsonaia kopuru jakin bat dauka. Ez dirudi eztabaida mamitsurik izan daitekeenik horrelako zerbaiti buruz. Kivyk dioenez, ordea, ez da berdin gertatzen termino deskriptibo ez-ebaluatibo guztiekin. Adibide bat ematen du: inbertsio melodikoa. Azaltzen duenez, eztabaidagarria da Beethovenen do diese (sostenitu) minorreko laukotean inbertsio melodikoa gertatzen den edo ez. Eta Kivyk badauka bere iritzia: Beethovenen asmoak dira giltza, ezin da ustekabeko inbertsiorik egon. Baina garrantzitsuena ez da hori. Garrantzitsuena da, esku artean dugun gaian, nolanahi ere, ezbaian ari direnek aurreposatzen dutela kontu objektibo bati bati buruz ari direla. Hori esaten du Kivyk.

Ebaluazioa dakarten terminoekin, hau da, «polit», «eder», edo «sublime» moduko terminoekin, kontua ez da horren erraza. Liburuaren gaira bueltatzen bagara («zergatik eztabaidatzen dugu?») erantzuna iguala da, hala ere. Eta honako hau da liburuan zehar Kivyk baieztatzen duen tesi nagusia: eztabaidatzaileok errealista estetikoak garelako eztabaidatzen dugu. Edo, bestela esanda, artelanak propietate estetiko ebaluatiboak badauzkala uste dugulako. Hori uste izateak soilik justifikatuko luke eztabaida.

Gerta liteke, ordea, nahiz eta guztiok hori uste izan eta hizkuntza arruntaren erabilerak hori aurresuposatu, errealismo estetikoa faltsua izatea. «Errorearen teoria» esaten zaio ikuspegi klase horri. Kivy ez dator bat horrekin. Eta esaten du zergatik. Liburu osoa errealismo estetikoaren aldeko defentsa- 
tzat har daiteke, baina ñabardura ere garrantzitsua da. Errealismo estetikoa faltsua dela erabakiko bagenu ere, arteari buruzko eztabaidak justifikatzeko nahikoa da eztabaidatzaileon jokabideak eta hizkuntzak hala aurresuposatzen dutela onartzea.

Propietate estetiko ebaluatiboen metafisikan aurkitzen dituzte batzuek errealismo estetikoaren egiaren kontrako zantzuak. Kivyk ez du hor problemarik ikusten. Bere ustez, propietate estetiko ebaluatiboak propietate pertzeptualak edo esperientzialak dira. Artelan batzuen propietate estetikoak ikusi (pinturan), entzun (musikan) edo biak (antzerkian) egiten baititugu. Nobela edo poesia isilik irakurtzean, ordea, zaila da propietate horiek hautematen ditugula esatea; esperimentatu (experience), sentitu edo bizi egiten ditugula esatea da agian egokiagoa.

Bigarren mailako propietateon ontologia lehen mailakoen «gainean datozen» (supervene) propietate «emergenteak» direla esanez azaldu nahi du. Propietate mentalen eta garun-propietate fisikoen arteko erlazioa azaltzeko proposatu izan da gainetortze erlazio hori. Elizabeth Barnesen (2012) definizioari segitzen dio Kivyk hemen. Nire uste apalean, azalpen mota hauek ez dute askorik argitzen, baina, tira, Kivyren argudioan ere ez dauka pisu handirik puntu honek. Bestalde, errealismo estetikoak errealismo moralak baino problema gutxiago dituela dio. Eta gogorarazten digu ez duela zertan egia izan gure desadostasunen berri emateko. Nahikoa da hori uste izatea eztabaidan direnek.

Edozein modutan, propietate estetiko ebaluatiboei buruzko eztabaida beste eztabaida nagusi baten zerbitzuan dagoela uste du Kivyk. Propietate horien presentziari buruz eztabaidatzen badugu, beste zerbaitetarako da batez ere: artelanaren meritu artistiko orokorrari buruz eztabaidatzeko, alegia. Eta horretaz ari da Kivy hamalaugarren kapituluan (The Truth of Evaluation).

Film bat ikusi ondoko bi lagunen arteko eztabaidarekin ilustratzen du Kivyk artelan baten meritu artistikoari buruz izan ohi dugun eztabaida. Gure judizio estetiko ebaluatibo orokorra justifikatzearren filmaren analisira jo dezakegu, bere propietate estetikoen eztabaidara. Lehen mailako propietate teknikoetara jo dezakegu, horiekin eta horiei buruz hitz egiteko terminoak menderatzen baditugu, bigarren mailako propietate estetiko lodi eta finei buruzko gure baiezpenak justifikatuz. Edo, film askoren kasuan behintzat, esanahira jo dezake eztabaidak. Halako ikuspegi moral edo politikoa transmititzea lagungarri zaion ala ez balio artistiko orokor positiborako. Kivyren puntu nagusia, beste behin, da maila hauetan guztietan errealismo estetikoa aurresuposatzen dela eta hori dela gustuari buruzko eztabaida horien esplikaziorik onena.

Horren kontra De gustibus non disputandum est plantea dezake norbaitek, eta, desadostasunaren, hots konbergentziarik ezaren, argudioa aurkeztu, 
Humek egin zuen moduan. Argudio horren arabera, errealismo estetikoa egiazkoa balitz, denborarekin dagoena baino adostasun zabalagoa lortuko litzateke; begi-bistakoa litzateke hainbat buru, horrenbeste aburu edo gustu daudela. Baina Kivyk kontra egiten die ondorio horiei, Humek hartutako bide beretik. Denborak aurrera egin ahala, adostasuna edo konbergentzia lortzen da, eta kanonak sortu ere sortzen dira: Mozart Bruckner baino hobetzat ezarri du denborak, Milton Ogilby baino hobetzat.

Liburua ixten duen hamabosgarren kapituluan (Common Sense and the Error Theory), argudio nagusiaren laburpena egin ondoren, errore teoriaren kontra egiten du bereziki Kivyk: hau da, eztabaida estetikoetan errealismoaren aurresuposizioa onartuta ere, aurresuposizio hori faltsua dela esaten duen teoria motaren kontra.

Kapituluen edukia banan-banan eta luze samar aurkeztu ondoren, kritika hau bukatzeko zilegi bekit bereziki interesatzen zaidan puntu batez aritzea. Zer baieztatzen dugu «X artelana ona da» esaten dugunean? Zein dira, esate baterako, «The Revenant film ona da» baieztapenaren egibaldintzak? Hori argitzea beharrezkoa da erabakitzeko beste bat «The Revenant film txarra da» edo «The Revenant ez da film ona» esanda benetan kontrakoa esaten ari ote zaion. Kivyren argudioa ulertu dudan heinean, «The Revenant film ona da» esaldia hainbat eratan uler daiteke. Hasteko, gustu pertsonalari buruzko baiezpen gisa uler daiteke ala judizio estetiko (ebaluatibo) orokor gisa. Edo, bestela esanda, gutxi gorabehera, (1) ala (2)ren baliokide gisa:

(1) The Revenant filma gustukoa dut.

(2) The Revenant meritu artistiko orokor handiko filma da.

Gustu pertsonal hutsez ari bagara, (1)en mailan ari bagara alegia, De Gustibus non Disputandum est printzipioa aplikatuko litzateke. Inork «The Revenant ez da film ona» da esanez, «Ez dut gustuko» baino ez luke baieztatuko, eta ez luke, horregatik, bestearen hasierako baiezpenarekin kontraesanik adieraziko. Bien arteko eztabaidak, beraz, ez luke zentzu handirik, nahiz kasu batzuetan, behintzat, harridura eragin lezakeen (besteen gustuak gureetatik desberdinak direnero sortzen zaigun harridura hori besterik ez).

Besterik da esaldiarekin artelanaren meritu artistiko orokorraz ari bagara. Kasu horretan eztabaida artistiko orokorrak zentzua dauka eta, errealismo estetikoa aurresuposatuta, «ona da» eta «ez da ona» baiezpen kontraesanezkoak dira. Bata egiazkoa; faltsua bestea. Eta argudioak eman daitezke nahiz zantzu objektiboak seinalatu, bataren alde eta bestearen kontra. Horretarako, baina, maila gehiago bereizi beharra dago, meritu estetiko orokorra, kasu batzuetan interpretazioak muga baitezake, eta kasu guztietan analisiak. Esan nahi baita, The Revenant filmaren kasuan, hizkuntz eta errepresentazio-esanahia dago jokoan; filmaren propietate artistiko ez-estetikoak, alegia. Kasu konkretu honetan, eztabaidagarria da, behinik behin, propietate horietako batzuek ez ote 
duten gainditzen filmak duen kalitate estetiko nabarmena, meritu artistiko orokorra ebaluatzean. Carol Cadwalladrek, adibidez, ezetz uste du:

Istorioa laburtuko dut zuentzat: gizona mendeku bila, gizonak mendekua lortu. Hori da guztia, oinarrian, bi ordu eta erdian, nahiz eta badagoen arnasaldi labur bat Leonardo DiCaprio ikusten duzunean hartz arre batek basaki erasoa... Beraz, paisaia hotza da eta bortxa arrazoigabea, eta guztia esanahirik gabea. Mendeku antzu baten ipuina, mina espektakulu gisa besterik ez dena. The Revenant minaren pornoa da. (Cadwalladr 2016) $)^{11}$

Cadwalladrek The Guardian egunkarian argitaratutako testu osoa irakurrita, argi geratzen da filma ez zaiola gustatu. Baina ez da gustu pertsonalaz soilik ari. Batez ere, filmaren esanahiaz ari da, propietate artistiko ez-estetikoez ari da, eta, Kivyri Gone with the Wind filmarekin gertatzen zaion bezala, islatzen dituen balio moral eskasak filmaren balio estetikoei gailentzen zaizkie meritu estetiko orokorra balioestean. Ez baitirudi balio estetiko horiek zalantzan jartzen dituenik, apenas eztabaidatzen dituen arren.

The Guardian egunkari horrexetan idatzitako kritikan, filmaren analisia egiten du Peter Bradshawk. «Larruari itsatsitako izotz izara bat bezain hotz eta zirraragarria da» 12 esanez laburbiltzen du (Bradshaw 2015). Kivyren teoriaren haritik tiraka, esango nuke «hotz» eta «zirraragarri» terminoak bigarren mailako propietate estetiko lodiak (deskriptiboak eta ebaluatiboak, eta positiboak, hain zuzen) direla Bradshawren erabileran. Badarabiltza bigarren mailako termino finak (ebaluatibo hutsak), eta baita termino deskriptibo hutsak ere. Eta termino horiek adierazten dituzten propietateak lehen mailako propietate estetikoetan oinarritzeko lana ere hartzen du Bradshawk. Filma propietate estetiko horien guztien jabe izanik, uste dut zilegi dela esatea meritu artistiko orokor handiko filma iruditzen zaiola. Eta esanahiaren aldetik ez zuela meritu hori murrizten zuen alderdirik topatu. Ez dakit iritzia aldatuko ote zuen gero Cadwalladren artikulua irakurrita. Baina, Kivyk zazpigarren kapituluan dioenaren haritik, honako aukera hauek planteatzen dira filmaren interpretazioaz: i) ez datoz bat filmaren interpretazioan eta desadostasunak bere horretan dirau; ii) bat datoz interpretazioan, baina Bradshawk ez du uste bere meritu artistikoari begira esanahia propietate estetikoei gailentzen zaienik. Edo iii) bat datoz, filmaren mezu hutsa minaren pornografia izanik, meritu artistiko orokor eskasa duela eta zentzu honetan «The Revenant ez da film ona» egiazkoa dela.

${ }^{11}$ I'll summarise the plot for you: man seeks revenge, man gets revenge. That's it, basically, for two and a half hours, though there is a brief reprieve when you get to see Leonardo DiCaprio being mauled by a grizzly bear... So the landscape is chilling and the violence is pointless and the whole thing is meaningless. A vacuous revenge tale that is simply pain as spectacle. The Revenant is pain porn.

${ }^{12}$ The movie is as thrilling and painful as a sheet of ice held to the skin. 
Filmaren propietate estetikoei dagokienez, zaila dirudi desadostasunari eusteak lehen mailako propietate estetikoei buruz. Aktoreen interpretaziolana, kameraren erabilera plano-sekuentzia luzeetan, paraje naturalen fotografia, argia, soinua... propietate zehatz hautemangarriak dira. Bigarren mailako propietate deskriptibo hutsen kasuan ere kontuak errazagoa dirudi. Eztabaidarako toki gehiago dagoela dirudi propietate ebaluatibo lodi edo finen atribuzioan, edo auzi batzuetan; adibidez, propietate batzuek (hala Bradshawk nola Cadwalldrek darabilten «basati» — brutal_, esate baterako) balio positiboa ala negatiboa dutelako auzian. Filmaren analisian, gutxi gorabehera bat datozela dirudi. Eztabaida interpretazioari (hots, esanahiari) buruzkoa da eta, agian, horrekin batera, filmaren ebaluazio artistiko orokorrean, interpretazioaren eduki moral eskasak analisian aurkitutako propietate estetikoei gailentzen ote zaizkien eztabaidatzen da. Nolanahi ere den, adibide bat besterik ez da hori. Hona ekartzeko arrazoia beste bat izan da.

Adibide horrekin erakutsi nahi izan dut Kivyk proposatutako teoriak lanabes egokiak eskaintzen dituela, oro har, artelanei buruzko kritikaren hainbat alderdi bereizteko eta, bereziki, judizio estetikoen egibaldintzak, judizio estetikoen arteko kontraesanak eta desadostasunak zeri buruzkoak diren argitzeko. Izan ere, gustuari buruzko desadostasunak eta bereziki «akatsik gabeko desadostasun» (faultless disagreement) gisa ezagutzen direnak oso eztabaidatuak izan dira azken urteotan hizkuntzaren filosofian, eta hainbat teoria aurkeztu dira gustuari buruzko baiezpenek duten proposizio-edukiari eta bere egiari buruz: erlatibismoa, kontestualismoa eta abar. Baina eztabaida horietan guztietan artearen filosofoen ekarpenen harira egindako propietate estetikoen berariazko eztabaida falta sumatzen da. Kivyren lan honek ekarpen garrantzitsua egin diezaieke hizkuntzaren filosofoei judizio estetikoen semantika eta pragmatikaren alorrean.

Argitu dugu, adibidez, «X artelan ederra da» esatean baiezpen desberdinak egin daitezkeela, edo maila desberdinetan uler daitezkeen baiezpenak, eta horrek desadostasunen eta kontraesanen azalpen xehea eskain dezakeela. Gustu pertsonalaren adierazpen soila izan daiteke, edo Xren meritu orokorrari buruzko baiezpena, edo, zehatzagoa, nola interpretazioari (esanahiari) hala analisiari (propietate estetikoei) buruzkoa. Ez dugu argitu hori nola esplikatzen den hobeki hizkuntzari gagozkiola: «eder» adjektiboa anbiguotzat joz, edo ezkutuko parametro bat gordetzen duen adjektibo gisa (indexikalismoaren bidetik) edo adjektibo zehaztugabe gisa, edo beste nolabait. Hori beste baterako utziko dugu.

Kivyk erakutsi digu errealismo estetikoa ez dela erraz baztertzeko modukoa eta, autore askok esan dutenaren kontra, zentzu gehiago daukala estetikan etikan baino. Hori baita estetikan dauzkagun eztabaiden azalpenik onena: eztabaidatzaileok errealismo estetikoa aurresuposatzen dugu eta ez dugu arrazoirik aurresuposizio hori faltsua dela esateko. 
Esango nuke garbi geratu dela liburu txikia baina mamitsua dela. Artean, estetikan eta filosofian interesa duenak irakurri beharko luke. Eta, Kivyren testu guztiak bezala, erraz eta gustura irakurtzen da. Ez dakit nolako musikaria den - oboea jotzen duela badakit-, baina, idatzi bezala jotzen badu, plazera izango da hari entzutea. Hizlari aparta da, hori ere badakit. Eta, ondo bidean, laster izango dugu berriz Donostian musikari eta literaturari buruz hitz egiteko. Ea horrek laguntzen duen arteari buruz inguru hauetan egiten ditugun juzgu, kritika eta eztabaidetan, filosofia eta estetika analitikoaren bidetik, zorroztasuna, argitasuna eta doitasuna indartzen.

\section{Erreferentzia bibliografikoak}

Ayer, Alfred J. (1936). Language, Truth and Logic. New York: Dover.

Bradshaw, Peter (2015). «The Revenant review - gut-churningly brutal, beautiful storytelling». The Guardian, 2015eko abenduaren 4a. https://www.theguardian. $\mathrm{com} /$ film/2015/dec/04/the-revenant-review-gut-churningly-brutal-beautifulstorytelling (2016ko uztailaren 21ean ikusia)

Cadwalladr, Carole (2016). «The Revenant is meaningless pain porn». The Guardian, 2016ko urtarrilaren 17a. https://www.theguardian.com/commentisfree/2016/ jan/17/revenant-leonardo-dicaprio-violent-meaningless-glorification-pain (2016ko uztailaren 21ean ikusia).

Elton, William (arg.) (1954). Aesthetics and Language. Oxford: Blackwell.

Frege, Gottlob (1892). «Über Sinn und Bedeutung,» in Zeitschrift für Philosophie und philosophische Kritik, 100: 25-50. Miguel Morik euskaratua, «Zentzu eta Erreferentziaz», in K. Korta (arg.), Hitzaren Lilura. Hizkuntzaren Filosofiako irakurgaiak. Bilbo: EHU, 2007, 37-59 or.

Grice, H. Paul (1957). «Meaning». Philosophical Review 66: 377-88. Kepa Kortak euskaratua, «Esanahia», in K. Korta (arg.), Hitzaren Lilura. Hizkuntzaren Filosofiako irakurgaiak. Bilbo: EHU, 2007, 145-155 or.

Hume, David (1742/1987). «The Sceptic». In Essays Moral, Political and Literary. Eugene F. Millerrek atondua, Indianapolis: Liberty Fund, 159-180 or.

Hume, David (1757/1987). «Of the Standard of Taste». In Essays Moral, Political and Literary. Eugene F. Millerrek atondua, Indianapolis: Liberty Fund, 226-249 or.

Kant, Immanuel (1790). Critique of Aesthetic Judgement. James Creed Meredithen itzulpena. Oxford: Oxford University Press. 2007.

Kivy, Peter (1973). Speaking of Art. The Hague: Martinus Nijhoff.

Kivy, Peter (1980). The Corded Shell: Reflections on Musical Expression. Princeton: Princeton University Press.

Kivy, Peter (1984). Sound and Semblance: Reflections on Musical Representation. Princeton: Princeton University Press.

Kivy, Peter (1989). Sound Sentiment: An Essay on Musical Emotions. Philadelphia: Temple University Press.

Kivy, Peter (1990). Music Alone. Philosophical Reflections on the Purely Musical Experience. New York: Cornell University Press.

Kivy, Peter (1993). The Fine Art of Repetition. Cambridge: Cambridge University Press. 
Kivy, Peter (2001). The Possessor and the Possessed. Handel, Mozart and Beethoven and the Idea of Musical Genius. New Haven: Yale University Press.

Kivy, Peter (2006). The Performance of Reading: An Essay on the Philosophy of Literature. Oxford: Blackwell.

Kivy, Peter (2007). Music, Language and Cognition. Oxford: Clarendon Press.

Kivy, Peter (2009). Antithetical Arts: On the Ancient Quarrel between Literature and Music. Oxford: Oxford University Press.

Korta, Kepa eta Jesus M. Larrazabal (arg.) (2004). Truth, Rationality and Cognition. Dordrecht: Kluwer.

Russell, Bertrand (1905). «On Denoting». Mind, 14, 479-493. Kepa Kortak euskaratua, «Denotatzeaz», in K. Korta (arg.), Hitzaren Lilura. Hizkuntzaren Filosofiako irakurgaiak. Bilbo: EHU, 2007, 61-77 or.

Sibley, Frank (1959). «Aesthetic Concepts». Philosophical Review 68: 421-50. Berrargitaratua in Peter Lamarque and Stein Haugom Olson (arg.), Aesthetics and the Philosophy of Art. The Analytic Tradition, Oxford: Blackwell, 2004, 127-141.

Urmson, J.O. (1957). «What makes a situation aesthetic?» Proceedings of the Aristotelian Society 31: 75-92.

Kepa Korta

ILCLI 